\title{
Kas-iskelet sistemi hastalıklarında stromal vasküler fraksiyon (SVF)
}

\section{Stromal vascular fraction in musculoskeletal system diseases}

\author{
Çağla Zübeyde Köprü ${ }^{1}$, Petek Korkusuz ${ }^{2}$, Feza Korkusuz ${ }^{3}$ \\ ${ }^{1}$ Yüksek İhtisas Üniversitesi, Histoloji ve Embriyoloji Anabilim Dalı, Ankara \\ ${ }^{2}$ Hacettepe Üniversitesi Tıp Fakültesi, Histoloji ve Embriyoloji Anabilim Dalı, Ankara \\ ${ }^{3}$ Hacettepe Üniversitesi Tıp Fakültesi, Spor Hekimliği Anabilim Dalı, Ankara
}

\begin{abstract}
Yağ dokusu, kas-iskelet sistemi dokularının onarım ve rejenerasyonunda kullanılabilecek zengin hücre kaynağı içerir. Yağ dokusu olgun adipositlerin yanı sıra stromal vasküler fraksiyon (SVF) içeren çok işlevli bir organdır. SVF, yağ dokusundan çeşitli yöntemler sonucu elde edilen heterojen bir hücre topluluğu olarak adlandırılır. SVF pre-adiposit, mezenkimal kök hücre (MKH), perisit, endotel hücresi ve makrofajları içerir; özellikle yağ kökenli kök hücrelerden (ADSC) zengindir. ADSC, sedasyon ve lokal anestezi altında kolay izole edildiğinden kemik iliği kökenli mezenkimal kök hücrelere (KI-MKH) alternatiftir. Yetişkin kök hücrelerinden yağ dokusu kökenli stromal/kök hücrelerin klinikte birçok avantajı bilindiği için son zamanlarda başta estetik amaçlı olmak üzere bu hücrelerin çeşitli hastalıklarının tedavisinde kullanılmaya başladığı görülmektedir. SVF ve MKH'ler doku iskeleleri üzerine eklenebilir ve sert doku (kemik ve kıkırdak yaralanmaları) ya da yumuşak doku defektlerinde (yara ve yanıklarda) hasarlı dokunun onarımında kullanılabilir. SVF'nin anjiyojenik, immün düzenleyici (anti-inflamatuvar), farklılaşmayı tetikleyici ve ekstrasellüler doku onarımını uyarıcı özellikler göstermesi de rejenerasyon ve onarım mekanizmalarındaki etkinliğini arttırır. Bu derlemenin amacı, SVF'nin özellikle kas-iskelet sistemi yaralanmaları ve hastalıklarında olmak üzere, tedavide kullanımına yönelik güncel gelişmeleri tartışmaktır.
\end{abstract}

Anahtar sözcükler: yağ dokusu; stromal vasküler fraksiyon; mezenkimal kök hücre; osteoartrit; osteoporoz; kas-iskelet sistemi
Adipose tissue has rich cell source for using in tissue engineering and regenerative medicine. Adipose tissue is a multifunctional organ containing mature adipocytes and stromal vascular fraction (SVF). SVF is termed as a heterogeneous cell population that can be derived from adipose tissue by various methods. SVF includes preadipocytes, mesenchymal stem cells (MSCs), pericytes, endothelial cells and macrophages. But it is especially rich in adipose-derived stem cells (ADSC). ADSC is an alternative to bone marrow-derived mesenchymal stem cells (BMMSCs) because it can be easily isolated. It is known that these adipose tissue-derived stromal/stem cells are used in the treatment of various diseases because of many clinical advantages. These cells can be seeded on tissue scaffolds and used for repair of damaged tissue as in hard tissue (bone and cartilage defects) or soft tissue defects (scars and burns). The ability of SVF to stimulate angiogenic, immunoregulatory, differentiation triggering and extracellular production also increases the efficiency of regeneration and repair mechanisms. In this article, especially in the musculoskeletal diseases, the use of SVF and strategies for treatment will be discussed.

Key words: adipose tissue; stromal vascular fraction; mesenchymal stem cell; osteoarthritis; osteoporosis; musculoskeletal system
E nerji depolanmasından sorumlu olan beyaz yağ dokusu iki ana bileşenden oluşur: olgun adipositler ve stromal vasküler fraksiyon (SVF). MKH'lerden köken alan olgun adipositler farklılaşırken PPAR $\gamma$, BMP-2, BMP-4 IGF-1 gibi faktörlere ihtiyaç duyar ama Wnt ailesi üyeleri adipogenezin erken basamaklarını engeller (Şekil 1). ADSC'leri izolasyon sonrası kültüre edilmeden bulunduran SVF, ilk olarak
1964 yılında, Rodbell tarafindan adipoz dokunun proteolitik enzimler ile sindirimi sonucu elde edilmiştir. Liposuction yöntemi ile elde edilen adipoz dokunun ekstrasellüler matriksi, kollajenaz enzimi ile sindirilir. Sindirim sonrası yapılan santrifüj işlemiyle elde edilen pellet SVF'dir. ${ }^{[1]}$ SVF; endotel hücresi, düz kas hücresi, eritrosit, lökosit, adiposit ve adipoz doku kökenli kök hücreleri içerir. ${ }^{[1-3]}$

- Illetişim adresi: Prof. Dr. Feza Korkusuz, Hacettepe Üniversitesi Tıp Fakültesi, Spor Hekimliği Anabilim Dalı, Sıhhiye, Ankara Tel: 0312 - 3051347 e-posta: feza.korkusuz@hacettepe.edu.tr

- Geliș tarihi: 20 Mart $2017 \quad$ Kabul tarihi: 20 Mart 2017 


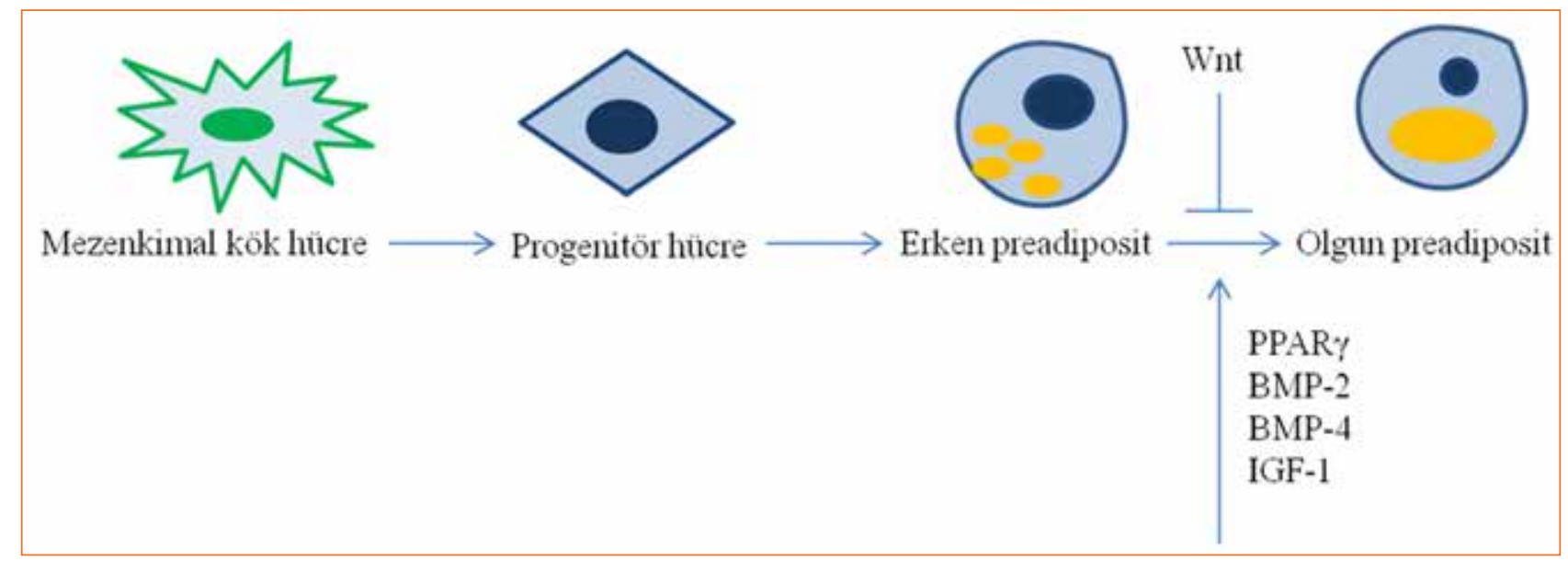

Şekil 1. Mezenkimal kök hücrelerin adipositlere farklanması (PPAR $\gamma$ : peroxisome proliferator activated receptor gamma; BMP-2: bone morphogenic protein-2; BMP-4: bone morphogenic protein-4; IGF-1: insulin growth factor-1).

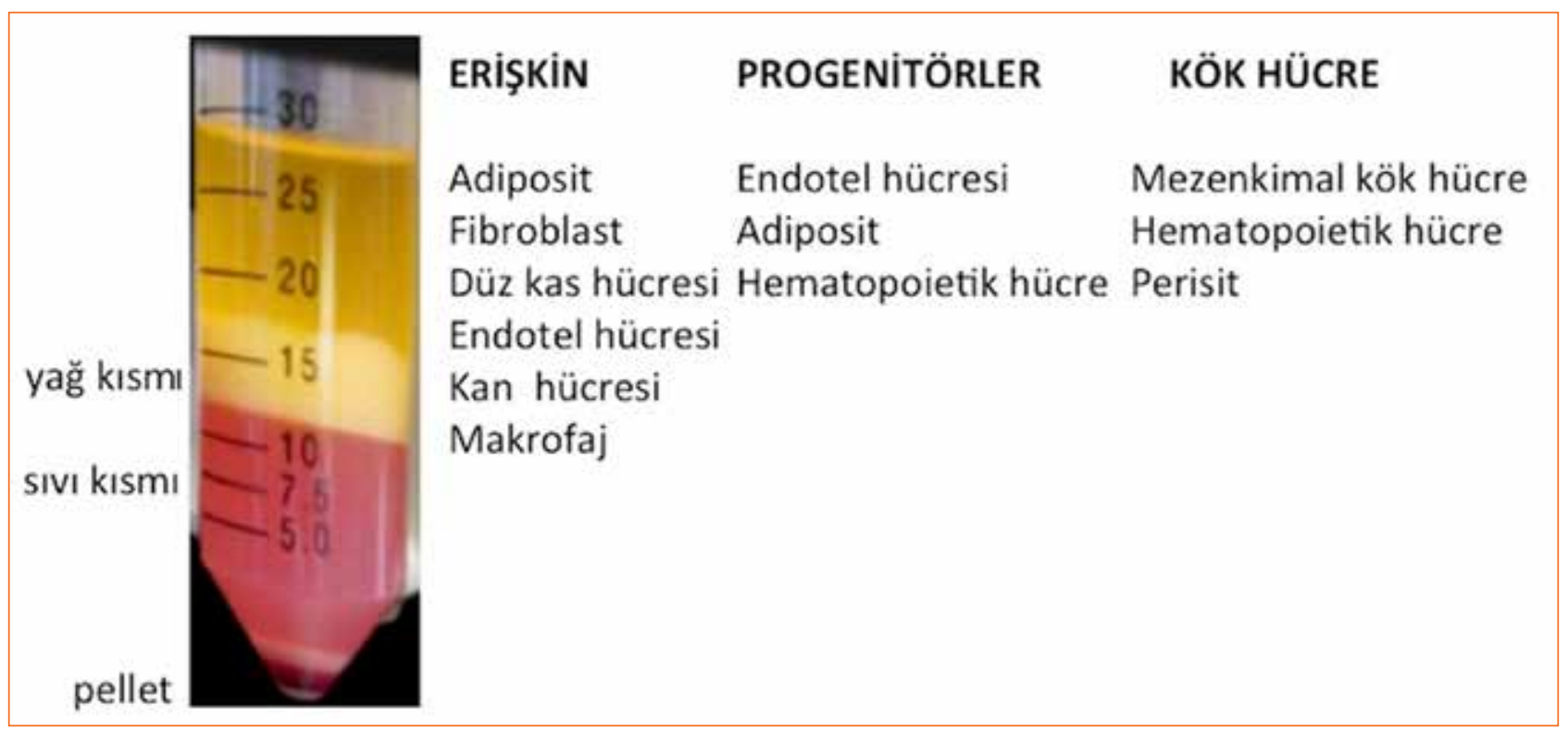

Şekil 2. SVF, birçok hücre tipinden oluşan heterojen bir hücre topluluğudur. Erişkin SVF'nin \%9'unu düz kas, \%7'sini endotel, \%22'sini kan ve \%23'ünü makrofaj hücreleri oluşturur. Adiposit ve fibroblast diğer hücrelerdir.

SVF; MKH, endotel öncülü hücre ve monosit/makrofajları içeren heterojen bir popülasyondur. ${ }^{[4,5]}$ Preadiposit, endotel öncülü hücre, düz kas hücresi, perisit, makrofaj ve fibroblast hücrelerini barındırır. ${ }^{[4]}$ Normal koşullarda, bu hücrelerin kültürü sonucu homojen bir mezodermal ya da MKH popülasyonu oluşur (Şekil 2).

MKH'lerin perivasküler bölgede kan damarları ile bağlantılı olarak yer aldığı düşünülür. Yağ dokusu kapiller damarlardan zengin olduğundan, bu bölge MKH'ler için iyi bir depodur. Yağ dokusundan izole edilmiş MKH'ler, burada adipoz doku kökenli kök hücreler
(ADSC) olarak adlandırılır. ${ }^{[1-3]} \mathrm{Bu}$ hücreler, Zuk tarafindan 2001 yılında karakterize edilmiştir. ${ }^{[6]}$ ADSC izolasyonu için tipik protokolde, beyaz yağ dokusundan kollajenaz sindirimi ve arkasından yüzen adipositleri ve pelletteki ADSC içeren SVF'yi ayırmak için santrifüj işlemi uygulanır. ${ }^{[7,8]}$ ADSC'ler, fibroblast benzeri iğsi görünümlüdür ve kemik iliğinden izole edilen $\mathrm{MKH}$ 'erin özelliklerini gösterir.

ADSC'lerin ifade ettiği yüzey belirteçleri; CD9, CD10, CD13, CD29 (integrin $\beta 1$ ), CD44 (hiyaluronan), CD49 (integrin $\alpha 4$ ), CD54, CD55, CD59, CD73, 


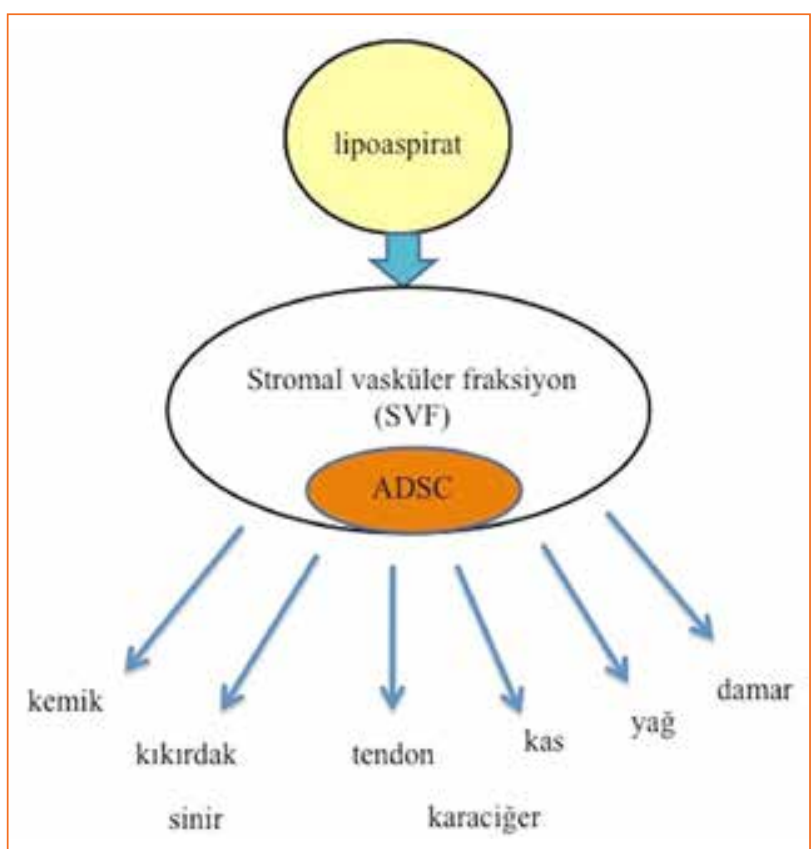

Şekil 3. SVF, yă̆ aldırma aspiratlarının kollajenaz ile muamelesi sonrası yağ dokusundan elde edilir. SVF, \%10-35 oranında ADSC ve lökosit gibi kan kökenli hücreleri içerir. (11 nolu kaynaktan geliştirilerek uyarlanmıştır)

CD90, CD105 (endoglin), CD106, CD146, CD166, HLA I, fibronektin, endomusin, ASMA, vimentin ve kollajen-I'dir.

ADSC'lerin ifade etmediği yüzey belirteçleri; CD11b, CD14, CD19, CD31, CD34, CD45, CD79 alfa, CD80, CD117 (cKit), CD133, CD144, HLA-DR, c-kit, MyD88, STRO-1, Lin ve HLA II'dir.

Yukarıda belirtilen belirteçlerden de anlaşılacağı gibi, ADSC'ler kemik iliği kaynaklı MKH'ler ile benzer öncül hücrelerden köken alır. Ancak, buna yönelik kesin bir deneysel sonuç bulunmamaktadır. ${ }^{[9]}$ ADSC'lerde HLADR ekspresyonunun görülmemesi, allojenik transplantasyonda doku reddini önler. ${ }^{[9]} \mathrm{Bu}$ nedenle, ADSC'ler MKH'lere alternatif olarak kullanılabilir.

Yapılan çalışmalarda, SVF'deki mezenkimal kök/ progenitör hücrelerin başarılı bir şekilde kültüre edilebildiği ve uygun koşullar altında adiposit, perisit, osteoblast, kondrosit ve miyoblastlara ve bu hücrelerin bulunduğu kemik, eklem kıkırdağı, tendon, iskelet kası ve yağ dokularına dönüşebildiği gösterilmiştir (Şekil 3). ${ }^{[10,11]}$ Bu nedenle MKH'ler, doku mühendisliği yaklaşımları ile birçok kalıtsal ya da kazanılmış, travmatik ya da dejeneratif kemik, eklem ve yumuşak doku hasarlarının tedavisinde kullanılır. ${ }^{[9,12-14]} \mathrm{Bu}$ hücreler aynı zamanda hücre iskeleleriyle birleştirilerek, sert ve yumuşak doku defektleri ile yara ve yanık tedavisinde de kullanılabilir. ${ }^{[13]}$

Bir çalışmada, MKH'lerin SVF'de kemik iliğinden 500 kat daha fazla bulunduğu bildirilmiştir. ${ }^{[15]}$ Ayrıca, SVF'nin yağ dokusundan kolaylıkla elde edilebilmesi, kemik iliği kökenli MKH'lere alternatif olarak düşünülmelerini sağlamıştır. Behfar ve arkadaşlarının 2014 yılında yaptıkları çalışmada, SVF'nin kemik iliği kaynaklı MKH'lere alternatif olarak kullanılabileceği, tendon yaralanmalarında gösterilmiştir. ${ }^{[16]} \mathrm{Bu}$ çalışmaların yanı sıra, SVF'nin etkinliği kemik ve kıkırdak yaralanmalarında da gösterilmiştir. Kıkırdak yenilenmesinin araştırıldığı bir çalışmada, kemik iliği kökenli hücreler ile karşılaştırıldığında, yağ dokusu kökenli SVF'nin bolca kök hücre içerdiği ve farklı hücre tiplerine hızlıca dönüşebildiği saptanmıştır. ${ }^{[17]} \mathrm{Kim}$ ve arkadaşları, SVF içeren MKH'lerin enjeksiyon sonrası etkinliğini ayak bileğinin osterokondral lezyonlarında incelemiş ve kıkırdak onarımının derecesini manyetik rezonans (MR) görüntüleme ile belirlemiştir. Sonuçta, MKH içeren SVF hücrelerinin, kemik iliği uyarımı ile beraber kullanıldığında, kemik iliğinin yalnız uyarımına göre daha etkili oldukları bildirilmiştir. ${ }^{[18]}$ Aynı zaman diliminde kemik iliği, kordon kanı ve yağ dokusundan elde edilen MKH'lerin morfolojisi, immünfenotipi, MKH elde etme başarısı, koloni yoğunluğu ve farklılaşma kapasitesi karşılaştırıldığında, anlamlı bir farklılık saptanmamıştır. ${ }^{[9]}$ Taze izole edilen SVF'nin kemik büyümesine etkisinin araştırıldığı diğer bir çalışmada, kemik hücrelerinin yenilenmesinde SVF ve bifazik kalsiyum fosfatla beraber kullanıldığında, yeni kemik oluşumu saptanamamıştır. ${ }^{[19]}$ SVF, kıkırdak doku yenilenmesinde de sıkça araştırılmaktadır. 2012 yılında yapılan bir çalışmada, trombositten zengin plazma (TZP) ile birlikte enjekte edilen SVF, farelerde eklem yenilenmesi sağlamıştır. Bu nedenle, eklem kıkırdağı hasarlarının tedavisinde TZP ile birlikte uygulanan SVF etkin rol oynayabileceği söylenebilir. ${ }^{[20]}$ Üzerinde hayvan çalışmalarının sıkça yapıldığı ADSC'lerin güvenilirliği, insan çalışmaları ile desteklenmelidir. Bu amaçla, TZP ile birlikte uygulanan SVF hücreleri birçok eklem bölgesine enjekte edilmiştir. Vizüel analog skalası (VAS) skorları ve MR sonuçlarına göre, ADSC/ TZP tedavisinin güvenilir olduğu saptanmıştır. ${ }^{[21]}$ Yine 2012 yılında yapılan bir başka çalışmada, osteonekroz tedavisi amacı ile, ADSC ile birlikte TZP verilmiştir. Burada TZP, gerekli olan büyüme faktörleri ve farklılaşmayı tetikleyen faktörleri sağlar. Ayrıca, TZP'nin kemik uyarımı, kan damarları ve kondrositlerin oluşumunda da pozitif etkileri bulunmaktadır. [22] Yapılan çalışma sonucunda kemik benzeri yapılar oluşmuştur ve bu, femoral baş osteonekroz tedavisi 
için umut vaat etmektedir. ${ }^{[23]} 2011$ yılında yapılan iki seri çalışmada ise, kalça osteonekrozu olan hastalara, ADSC, HA, TZP ve kalsiyum klorid karışımı enjekte edilmiş ve kemik hücrelerinin yenilendiği görülmüş̧ür. Aynı karışıma düşük dozda deksametazon eklendiğinde ise, diz osteoartriti (OA) olan hastalarda kıkırdak yenilenmesi belirlenmiştir. ${ }^{[24]}$

SVF ile tedavide avantaj, sadece MKH barındırması değil aynı zamanda regülatuvar T hücresi (Treg) de içermesidir. Adipoz doku, diğer periferal bölgelere göre daha fazla Treg barındırır. Çünkü, Treg'ler de anti-inflamatuvar özellikler gösterir. Bu iki hücrenin SVF şeklinde birlikte uygulanması immün toleransı arttırır. ${ }^{[25]}$ Örneğin; romatoid artritli hastalarda yapılan bir çalışmada, hastalarda iyileşme gözlenmiş ve burada Treg'lerin etkinliğinden bahsedilmiştir. ${ }^{[26]}$

\section{ADSC'LERIN HAZIRLANMASI VE KARAKTERIZASYONU}

Fibroblast benzeri yapıda olan ADSC'lerin izolasyonu ve kültürü, farklı dokulardan elde edilen MKH’lerin kültürü ile benzerlik gösterir. ADSC'ler, adipositlere, miyositlere, kondrositlere ve osteositlere dönüşme kapasitesine sahiptir. ${ }^{[9]}$ Hücresel kompozisyon, tür, yaş, izolasyon yöntemi, kültür koşulları, pasaj sayısı gibi faktörler, ADSC'lerin proliferasyon oranını ve dönüşme kapasitesini etkiler. ${ }^{[27]}$ Örneğin; pasaj 0'da, insan ya da kemirici ADSC'leri \%10'dan daha az miktarda CD31 içerir. ${ }^{[27]}$ Ameliyat tipi ve yağ dokusunun alındığı bölge, SVF'den elde edilen toplam canlı hücre sayısını etkileyebilir. Kemiricilerde SVF'nin hücre içeriği ve dönüşme kapasitesi yağ dokusunun bulunduğu yere göre farklılık gösterirken, insanlarda bu konuyla ilgili sınırlı bilgi vardır. Genel kabul gören pratik uygulama, abdominal bölgeden alınan yağ dokusundan SVF üretilmesi yönündedir. ${ }^{[28]}$ Liposuction yöntemi ile dokunun ayrıştırılması da genel kabul görmüştür. ${ }^{[29]}$ Liposuction sırasında, tumescent çözeltisinin kullanılması ve dört farklı bölgeden $100 \mathrm{~mL}$ civarında doku alınması önerilir. ${ }^{[30]}$ Farklı anatomik bölgelerde bulunan yağ dokusunun kendine özel metabolik özellikleri vardır ve bu da, uzun dönemde yağ greftlerinin karakterini etkiler. Bu nedenle, ileride yapılacak çalışmalarda, farklı anatomik bölgelerden elde edilen ADSC'lerin hücre tedavisi sonrası farklı metabolik ve hücresel davranışlar gösterip göstermeyeceği araştırılmalıdır. ${ }^{[9]}$

SVF, lipoaspirat hücrelerinden ultrasonik kavitasyon ya da kollajenaz ile ayrılabilir. Kollajenaz enzimi ile SVF elde edilmesinde ise, adipoz doku enzim ile sindirilir ve santrifüj edilir. Elde edilen pellet SVF'dir. ${ }^{[1]}$ Daha sonra SVF hücreleri, akım sitometri cihazı ile ifade ettikleri belirteçlere göre ayrılır.
ADSC'ler, vasküler endoteliyal büyüme faktörü (VEGF), hepatosit büyüme faktörü (HGF), insülin benzeri büyüme faktörü 1 (IGF-1) gibi büyüme faktörlerini salgılar. Tümör nekrozis faktör alfa (TNF-alfa), VEGF, HGF ve IGF-1'in ADSC'lerden uyarımını arttırır. ADSC'lerin proliferasyonunu düzenleyen moleküler mekanizmaların bilinmesi, izolasyon ve kültür prosedürlerinin geliştirilmesinde yardımcı olacaktır. ${ }^{[9]}$

\section{ADSC'LERIN KLINIK UYGULAMALARI}

MKH’ler, kök hücre kaynağı olarak sıkça kullanılır. Fakat, klinik uygulamalarda fazla sayıda hücreye ihtiyaç duyulduğundan, kemik iliği aspirasyonu uygulanmaktadır. ${ }^{[31]}$ Kemik iliği kaynaklı MKH'lerin kıkırdak yenilenmesinde etkili oldukları bilinmektedir. Fakat klinik uygulamalarda, pahalı olması ve aspirasyonun ağrılı olması gibi nedenlerden ötürü dezavantajlıdır. ${ }^{[32]}$ MKH'lere alternatif olarak yetişkin kök hücre kaynağını çokça bulunduran yağ dokusu bu nedenle gündemdedir. ADSC'ler kemik iliği kökenli MKH'lere göre daha kolay elde edilebilir ve daha ucuzdur. ${ }^{[6]}$ Yağ dokudan köken alan SVF, kendini yenileyen hücre popülasyonları içerir ve bu nedenle, birçok hastalığın tedavi sürecinde ve yaralanmış dokuların yenilenmesinde etkilidir. ${ }^{\left[{ }^{[3}\right.}$

OA, eklem kıkırdağının dejenerasyonu ile giden yaygın bir hastalıktır. ${ }^{[5]}$ Son yıllarda yapılan çalışmalarda SVF'nin OA'lı hastaların acı ve inflamasyonunun azaltılmasındaki etkinliği araştırılmaktadır. Diz OA'sı olan hastalarda adipoz kökenli SVF'nin ağrıyı azalttığı ve fonksiyonu iyileştirdiği gösterilmiştir. [33]

Eklem kıkırdağı hasarına neden olan dejeneratif hastalıkların başında gelen OA'nın tedavisinde MKH'lerin güvenilir ve etkin olduğu, hayvan deneylerinde gösterilmiştir. ${ }^{[34]}$ Kemik iliği ve yağ dokusundan izole edilebilen MKH'ler farklılık gösterebilmektedir. ADSC'ler uzun dönem kültürlerde genetik olarak daha kararlıdır ve yüksek çoğalma kapasitesi vardır. Standart liposuction yöntemiyle elde edilen yağ dokusundan izole edilen SVF, \%1-4 oranında MKH içerir. SVF hücreleri, klinikte taze olarak çoğaltmaya ihtiyaç duyulmadan kullanılabilir. Taze olarak kullanılabilen hücreler, ex vivo bir işlemden geçirilmediğinden, $\mathrm{MKH}$ 'lere göre daha avantajlıdır. ${ }^{[35]}$ Otolog adipoz kökenli SVF hücre tedavisi OA'da sıkça kullanılmakta ve klinik skorlama testlerinde iyileşme görülmektedir. Tablo 1'de, OA tedavisinde kullanılan SVF hücreleri ile ilgili çalışmalara örnekler verilmiştir. ${ }^{[5,18,35-37]}$

In vitro deneyler ve klinik çalışmalara dayanılarak, ADSC'lerin klinikte sıkça kullanıldığı bilinmektedir. Klinikte ADSC'lerin kullanıldığı ve en çok rapor edilen hastalıkların başında, meme konstriksiyonu ve fistül tedavisi gelmektedir. Tablo 2'de SVF ve ADSC'lerin 
Tablo 1. OA tedavisinde kullanılan SVF hücreleri ile ilgili çalışmalara örnekler

\begin{tabular}{|c|c|c|c|c|}
\hline Uygulanan işlem & Uygulanan bölge & Hasta grubu & Sonuç & Kaynak \\
\hline MKH içeren SVF & Ayak bileği & $\begin{array}{l}\text { Talusu osteokondral } \\
\text { lezyonlu hastalar (OLT) }\end{array}$ & $\begin{array}{l}\text { OLT tedavisinde } \\
\text { kullanılabilir. }\end{array}$ & Kim, 2014 \\
\hline SVF+ plazma & Diz ve kalça eklemi & 1114 grade $2-4 \mathrm{OA}$ & $\begin{array}{l}\text { Enfeksiyon ve kanser } \\
\text { gelişmemiş, KOSS/HOSS, } \\
\text { Ăgrı, yürüyüş̧ ve hareket } \\
\text { artmıştır. }\end{array}$ & Michalek, 2015 \\
\hline SVF & Diz & Grade 2-3 OA & $\begin{array}{l}\text { Enfeksiyon görülmemiş, } \\
\text { ağrı azalmıştır. }\end{array}$ & Garza, 2015 \\
\hline $\mathrm{SVF}+\mathrm{TZP}+\mathrm{HA}$ & Diz & $\mathrm{OA}$ & $\begin{array}{l}\text { Kıkırdak benzeri doku } \\
\text { yenilenmesi, acı ve } \\
\text { fonksiyonel kaybın } \\
\text { azalması saptanmıştır. }\end{array}$ & Pak, 2016 \\
\hline SVF+TZP & Diz & Grade 2 ya da $3 \mathrm{OA}$ & $\begin{array}{l}\text { WOMAC skorları ve } \\
\text { acıda azalma, Lysholm } \\
\text { ve VAS skorlarında artış } \\
\text { gözlenmiştir. }\end{array}$ & Nguyen, 2016 \\
\hline
\end{tabular}

Tablo 2. SVF ve ADSC'lerin kullanıldığı klinik çalışmalar (38)

\begin{tabular}{lllll}
\hline Hastalık & Dizayn & Çalışma tipi & Sonuç & Kaynak \\
\hline Meme rekonstriksiyonu & Otolog SVF & Faz IV & Tamamlanmış & NCT00616135 $^{\text {a }}$ \\
Koroner hastalık & Otolog SVF & Faz I & Devam ediyor & NCT00426868 $^{\text {a }}$ \\
Fistül & Otolog ADSC & Faz I ve II & Tamamlanmış & NCT00992485 $^{\text {a }}$ \\
Spinal kord yaralanması & Otolog ADSC & Faz I & Tamamlanmış & NCT01274975 $^{\text {a }}$ \\
Diyabet & Otolog ADSC & Faz I ve II & Bilinmiyor & NCT00703599 $^{\text {a }}$ \\
\hline
\end{tabular}

${ }^{a}$ klinik denemeler web sitesinde tanımlayıcı: http://clinicaltrials.gov

klinikte kullanıldığı çalışmalara örnekler verilmiştir. ${ }^{[38]}$ Otolog SVF'nin kas-iskelet sistemi rahatsızlıklarındaki etkinliği, halen yapılan birçok çalışma ile gösterilmekte ve bu nedenle SVF, hücre bazlı tedavi seçenekleri arasinda tercih edilmektedir.

\section{SONUÇ}

SVF, kas-iskelet sistemi dokularının onarım ve rejenerasyonunda kullanılabilecek zengin hücre kaynağı içerir. Stromal vasküler fraksiyonun içindeki hücrelerin yaklaşık \%30'u kök hücre özelliği gösterir. Bu hücrelerin inflamasyonu azaltıcı ve immüniteyi düzenleyici etkileri belirgindir. Çoğunlukla, trombositten zengin plazma ile birlikte kullanıldığında doku onarıcı özellik gösterdikleri belirlenmiştir. Bu hücreler osteoartrit tedavisinde, kaynama yokluğunda ve femur başı avasküler nekrozu gibi hastalıkların tedavisinde deneysel amaçla kullanılmaktadır.

\section{KAYNAKLAR}

1. Kasir R, Vernekar VN, Laurencin CT. Regenerative Engineering of Cartilage Using Adipose-Derived Stem Cells. Regen Eng Transl Med 2015;1(1):42-9. Crossref
2. Köprü ÇZ, Korkusuz P, Vargel I, Korkusuz F. Stromal vasküler fraksiyon. In: Korkusuz F, editor. Temel Bilimler ve Araştırma Kitabı. Ankara: Pelin Ofset; 2016. p.265-71.

3. Köprü ÇZ, Korkusuz P, Vargel I, Korkusuz F. Stromal vasküler fraksiyon. In: Taşer ÖF, Tuncay i, editörler. Eklem İçi Enjeksiyonlar. İstanbul: ITK Basım; 2016. p.51-62.

4. Ghidoni I, Chlapanidas T, Bucco M, Crovato F, Marazzi M, Vigo D, Torre ML, Faustini M. Alginate cell encapsulation: new advances in reproduction and cartilage regenerative medicine. Cytotechnology 2008;58:49-56. Crossref

5. Garza JR, Maria DS, Palomera T, Dumanian GA, Dos-Anjos S. Use of Autologous Adipose-Derived Stromal Vascular Fraction to Treat Osteoarthritis of the Knee: A Feasibility and Safety Study. J Regen Med 2015;4:1. Crossref

6. Zuk PA, Zhu M, Mizuno $H$, Huang J, Futrell JW, Katz AJ, Benhaim P, Lorenz HP, Hedrick MH. Multilineage cells from human adipose tissue: implications for cell-based therapies. Tissue Eng 2001;7(2):211-28. Crossref

7. Gimble JM, Katz AJ, Bunnell BA. Adipose-derived stem cells for regenerative medicine. Circ Res 2007;100(9):1249-60. Crossref

8. Silva KR, Liechocki S, Carneiro JR, Claudio-da-Silva C, MayaMonteiro CM, Borojevic R, Baptista LS. Stromal-vascular fraction content and adipose stem cell behavior are altered in morbid obese and post bariatric surgery ex-obese women. Stem Cell Res Ther 2015;6:72. Crossref

9. Schäffler A, Büchler $C$. Concise review: adipose tissue-derived stromal cells -basic and clinical implications for novel cellbased therapies. Stem Cells 2007;25(4):818-27. Crossref 
10. Koh YJ, Koh BI, Kim H, Joo HJ, Jin HK, Jeon J, Choi C, Lee $\mathrm{DH}$, Chung JH, Cho CH, Park WS, Ryu JK, Suh JK, Koh GY. Stromal vascular fraction from adipose tissue forms profound vascular network through the dynamic reassembly of blood endothelial cells. Arterioscler Thromb Vasc Biol 2011;31(5):1141-50. Crossref

11. Yoshimura K, Sato K, Matsumoto D. Cell-assisted lipotransfer for breast augmentation: grafting of progenitor-enriched fat tissue. In: Shiffman MA, editor. Autologous Fat Transfer. Berlin, Heidelberg: Springer-Verlag; 2010. p.261-71. Crossref

12. Aydin HM, Korkusuz P, Vargel I, Uckan D, Guzel E, Cavusoglu T, Kilic E, Pişkin E. Invetigation of polymer/mesenchymal stem cell constructs for cranial defects: 6-months in vivo study. J Bioactive and Compatible Polymers 2011;26(2):207-21.

13. Korkusuz P, Kose S, Kopru CZ. Biomaterial And Stem Cell Interactions: Histological Biocompatibility. Curr Stem Cell Res Ther 2016;11(6):475-86.

14. Bölgen N, Korkusuz P, Vargel I, Kılıç E, Güzel E, Çavuşoğlu T, Uçkan D, Pişkin E. Stem cell suspension injected HEMAlactate-dextran cryogels for regeneration of critical sized bone defects. Artif Cells Nanomed Biotechnol 2014;42(1):70-7. Crossref

15. Fraser JK, Wulur I, Alfonso Z, Hedrick MH. Fat tissue: an underappreciated source of stem cells for biotechnology. Trends Biotechnol 2006;24(4):150-4. Crossref

16. Behfar M, Javanmardi S, Sarrafzadeh-Rezaei F. Comparative study on functional effects of allotransplantation of bone marrow stromal cells and adipose derived stromal vascular fraction on tendon repair: a biomechanical study in rabbits. Cell J 2014;16(3):263-70.

17. Jang Y, Koh YG, Choi YJ, Kim SH, Yoon DS, Lee M, Lee JW. Characterization of adipose tissue-derived stromal vascular fraction for clinical application to cartilage regeneration. In Vitro Cell Dev Biol Anim 2015;51(2):142-50. Crossref

18. Kim YS, Lee HJ, Choi YJ, Kim Y, Koh YG. Does an injection of a stromal vascular fraction containing adipose-derived mesenchymal stem cells influence the outcomes of marrow stimulation in osteochondral lesions of the talus? A clinical and magnetic resonance imaging study. Am J Sports Med 2014;42(10):2424-34. Crossref

19. Thery A, Bléry P, Malard O, Pilet P, Sourice S, Corre P, Guicheux J, Weiss P, Espitalier F. Role of the stromal vascular fraction from adipose tissue in association with a phosphocalcic scaffold in bone regeneration in an irradiated area. J Craniomaxillofac Surg 2015;43(7):1169-76. Crossref

20. Van Pham P, Hong-Thien Bui K, Quoc Ngo D, Tan Khuat L, Kim Phan N. Transplantation of nonexpanded adipose stromal vascular fraction and platelet-rich plasma for articular cartilage injury treatment in mice model. J Med Eng 2013;2013:7.

21. Pak J, Chang JJ, Lee JH, Lee SH. Safety reporting on implantation of autologous adipose tissue-derived stem cells with platelet-rich plasma into human articular joints. BMC Musculoskelet Disord 2013;14:337. Crossref

22. Parsons P, Hesselden K, Butcher A, Maughan J, Milner R, Horner A. The biological effect of platelet rich-plasma on the fracture healing process. Orthopaedic Proceedings 2009;91B(Suppl II):293.

23. Pak J. Autologous adipose tissue-derived stem cells induce persistent bone-like tissue in osteonecrotic femoral heads. Pain Physician 2012;15(1):75-85.

24. Pak J. Regeneration of human bones in hip osteonecrosis and human cartilage in knee osteoarthritis with autologous adipose-tissue-derived stem cells: a case series. J Med Case Rep 2011;5:296. Crossref
25. Rodriguez JP, Murphy MP, Hong S, Madrigal M, March KL, Minev B, Harman RJ, Chen CS, Timmons RB, Marleau AM, Riordan NH. Autologous stromal vascular fraction therapy for rheumatoid arthritis: rationale and clinical safety. Int Arch Med 2012;5:5. Crossref

26. Ichim TE, Harman RJ, Min WP, Minev B, Solano F, Rodriguez $\mathrm{JP}$, Alexandrescu DT, De Necochea-Campion R, Hu X, Marleau AM, Riordan NH. Autologous stromal vascular fraction cells: a tool for facilitating tolerance in rheumatic disease. Cell Immunol 2010;264(1):7-17. Crossref

27. Lin CS, Xin ZC, Deng CH, Ning H, Lin G, Lue TF. Defining adipose tissue-derived stem cells in tissue and in culture. Histol Histopathol 2010;25(6):807-15. Crossref

28. Perdisa F, Gostyska N, Roffi A, Filardo G, Marcacci M, Kon E. Adipose-Derived Mesenchymal Stem Cells for the Treatment of Articular Cartilage: A Systematic Review on Preclinical and Clinical Evidence. Stem Cells Int 2015;2015:597652. Crossref

29. Housman TS, Lawrence N, Mellen BG, George MN, Filippo JS, Cerveny KA, DeMarco M, Feldman SR, Fleischer AB. The safety of liposuction: results of a national survey. Dermatol Surg 2002;28(11):971-8.

30. Bunnell BA, Flaat M, Gagliardi C, Patel B, Ripoll C. Adiposederived stem cells: isolation, expansion and differentiation. Methods 2008;45(2):115-20. Crossref

31. Pittenger MF, Mackay AM, Beck SC, Jaiswal RK, Douglas R, Mosca JD, Moorman MA, Simonetti DW, Craig S, Marshak DR. Multilineage potential of adult human mesenchymal stem cells. Science 1999;284(5411):143-7.

32. Fortier LA, Potter HG, Rickey EJ, Schnabel LV, Foo LF, Chong LR, Stokol T, Cheetham J, Nixon AJ. Concentrated bone marrow aspirate improves full-thickness cartilage repair compared with microfracture in the equine model. J Bone Joint Surg Am 2010;92(10):1927-37. Crossref

33. Koh YG, Jo SB, Kwon OR, Suh DS, Lee SW, Park SH, Choi YJ. Mesenchymal stem cell injections improve symptoms of knee osteoarthritis. Arthroscopy 2013;29(4):748-55. Crossref

34. Keerthi $N$, Chimutengwende-Gordon M, Sanghani A, Khan $W$. The potential of stem cell therapy for osteoarthritis and rheumatoid arthritis. Curr Stem Cell Res Ther 2013;8(6):444-50.

35. Michalek J, Moster R, Lukac L, Proefrock K, Petrasovic M, Rybar J, Capkova M, Chaloupka A, Darinskas A, Michalek J Sr, Kristek J, Travnik J, Jabandziev P, Cibulka M, Holek M, Jurik M, Skopalik J, Kristkova Z, Dudasova Z. Autologous adipose tissue-derived stromal vascular fraction cells application in patients with osteoarthritis. Cell Transplant 2015. Crossref [Epub ahead of print]

36. Pak J, Lee JH, Park KS, Jeong BC, Lee SH. Regeneration of Cartilage in Human Knee Osteoarthritis with Autologous Adipose Tissue-Derived Stem Cells and Autologous Extracellular Matrix. Biores Open Access 2016;5(1):192-200. Crossref

37. Nguyen PD, Tran TD, Nguyen HT, Vu HT, Le PT, Phan NL, Vu NB, Phan NK, Van Pham P. Comparative Clinical Observation of Arthroscopic Microfracture in the Presence and Absence of a Stromal Vascular Fraction Injection for Osteoarthritis. Stem Cells Transl Med 2016. pii: sctm 2016-0023. Crossref [Epub ahead of print]

38. Mizuno H, Tobita M, Uysal AC. Concise review: Adiposederived stem cells as a novel tool for future regenerative medicine. Stem Cells 2012;30(5):804-10. Crossref 